Review

\title{
The Functions and Therapeutic Potential of Heat Shock Proteins in Inflammatory Bowel Disease-An Update
}

\author{
Abdullah Hoter ${ }^{1,2}$ and Hassan Y. Naim $2, *$ (iD \\ 1 Department of Biochemistry and Chemistry of Nutrition, Faculty of Veterinary Medicine, Cairo University, \\ Giza 12211,Egypt; abdullah.hoter@vet.cu.edu.eg or abdo_hotar@yahoo.com \\ 2 Department of Physiological Chemistry, University of Veterinary Medicine Hannover, \\ 30559 Hannover, Germany \\ * Correspondence: hassan.naim@tiho-hannover.de; Tel.: +49-511-953-8780; Fax: +49-511-953-8585
}

Received: 11 October 2019; Accepted: 25 October 2019; Published: 26 October 2019

\begin{abstract}
Inflammatory bowel disease (IBD) is a multifactorial human intestinal disease that arises from numerous, yet incompletely defined, factors. Two main forms, Crohn's disease (CD) and ulcerative colitis (UC), lead to a chronic pathological form. Heat shock proteins (HSPs) are stress-responsive molecules involved in various pathophysiological processes. Several lines of evidence link the expression of HSPs to the development and prognosis of IBD. HSP90, HSP70 and HSP60 have been reported to contribute to IBD in different aspects. Moreover, induction and/or targeted inhibition of specific HSPs have been suggested to ameliorate the disease consequences. In the present review, we shed the light on the role of HSPs in IBD and their targeting to prevent further disease progression.
\end{abstract}

Keywords: heat shock proteins; inflammatory bowel disease; Crohn's disease; ulcerative colitis; chaperones; therapeutic function

\section{Introduction}

Inflammatory bowel disease (IBD) is a chronic inflammatory disorder of the gastrointestinal tract that implies dysregulated intestinal homeostasis. Clinically, IBD falls into two major types: Crohn's disease (CD), which can impact any part of the gastrointestinal tract, and ulcerative colitis (UC), which displays restricted pathology to the colon [1] (see Figure 1). In fact, a complete knowledge of the exact mechanism that leads to the disease is still obscure; however, several factors contributing to the pathogenesis of IBD have been identified [1,2]. 

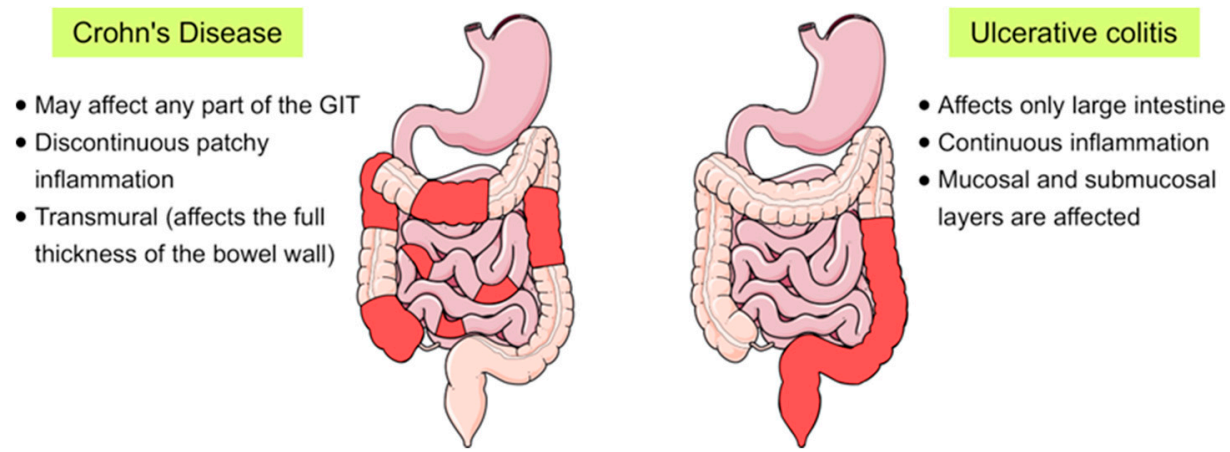

Figure 1. Schematic representation showing the main differences between the two main forms of inflammatory bowel disease (IBD), Crohn's disease and ulcerative colitis, in terms of their location and the pattern of the affected areas (red-coloured) in the gastrointestinal tract (GIT).

IBD results from multifaceted factors which include genetic predisposition, environmental factors, smoking, dietary factors, intestinal microbiota and alterations in the function of the immune system [2,3]. It is believed that a complex interplay between these factors and host innate immunity can initiate the disease $[1,3]$. In accordance with these observations, our group has recently revealed that pro-inflammatory mediators including $\mathrm{TNF} \alpha, \mathrm{MCP} 1$ and IL-1 $\beta$, whose levels are frequently elevated in IBD, can induce endoplasmic reticulum (ER) stress and alter the function and trafficking of key proteins of the intestinal brush border membranes [4]. Owing to the aforementioned complex factors and overlapping mechanisms along with the heterogenic nature of IBD, the disease has been recently identified as an ailment of "complex and variable" nature [5].

Heat shock proteins (HSPs) are highly conserved, stress-induced molecules that are ubiquitously expressed in all eukaryotic cells. These proteins are classically categorized according to their molecular mass into six major families whose members range from 10 to $170 \mathrm{kDa}$ [6,7]. In addition, Kampinga and his colleagues provided an alternative classification that names HSP members in the form of a letter/number combination [8] (Table 1).

Table 1. Summary of heat shock proteins (HSP) families and their common members.

\begin{tabular}{|c|c|c|c|}
\hline HSP Family & Alternative Family Name & Number of Members & Common Selected Members \\
\hline HSP110 & $\mathrm{HSPH}$ & 4 & $\begin{array}{c}\text { HSPH1 (HSP105), HSPH2 } \\
\text { (HSP110, HSPA4) }\end{array}$ \\
\hline HSP90 & HSPC & 5 & $\begin{array}{c}\text { HSPC2 (HSP90 } \alpha \text { ), HSPC3 } \\
\text { (HSP90ß), HSPC4 (GRP94, } \\
\text { HSP90B1, GP96, endoplasmin), } \\
\text { HSPC5 (TRAP1, HSP75, HSP90L) }\end{array}$ \\
\hline HSP70 & HSPA & 13 & $\begin{array}{l}\text { HSPA1A (HSP70-1), HSPA1B } \\
\text { (HSP70-2) HSPA5 (BIP, GRP78), } \\
\text { HSPA6 (HSP70B'), HSPA8 } \\
\text { (HSC70), HSPA9 (GRP75) }\end{array}$ \\
\hline $\begin{array}{l}\text { HSP60 and HSP10 } \\
\text { (Chaperonins) }\end{array}$ & HSPD and HSPE & 14 & HSPD1 (HSP60), HSPE1 (HSP10) \\
\hline HSP40 & DNAJ & 50 & $\begin{array}{c}\text { DNAJA1, DNAJB1 (HSPF1 and } \\
\text { HSP40), DNAJC1 }\end{array}$ \\
\hline Small HSPs & HSPB & 11 & $\begin{array}{c}\text { HSPB1 (HSP27), HSPB4 (CRYAA) } \\
\text { and HSPB5 (CRYAB) }\end{array}$ \\
\hline
\end{tabular}

Functionally, HSPs differ in their ATP requirements, with high-molecular-weight HSPs needing ATP for their proper function, hence called "ATP-dependent", and HSPs of small molecular weight (or small HSPs, sHSPs) being "ATP-independent" [9,10]. The principle functions of HSPs are folding of newly synthesized proteins, refolding of misfolded or denatured proteins and prevention of their 
aberrant aggregation, collectively known as "chaperone activities" [11-13]. Other house-keeping functions include protein trafficking and transport between different cellular compartments, besides their secretory and immunological functions [14-17]. Expression of HSPs is primarily regulated via "heat shock response (HSR)" in which heat shock factor 1 (HSF1) and other transcription factors control the transcription of variant chaperone proteins [18,19]. Notably, HSPs exhibit either a constitutive or an induced expression pattern by which certain members are continuously expressed in non-stress conditions or only expressed/overexpressed after induction by specific stress factors, respectively. Indeed, many physiological and environmental stress factors, such as heat stress, toxic agents, hypoxia, heavy metals, tissue development and differentiation, can induce high expression of HSPs in intestinal epithelial cells [6,20,21] (Figure 2). The upregulation of HSPs accompanies several pathological conditions and inflammatory processes and is involved in the pathogenesis of a multitude of autoimmune and chronic inflammatory diseases such as rheumatoid arthritis [22], atherosclerosis [23], diabetes mellitus [24], myasthenia gravis [25] and IBD [26,27].

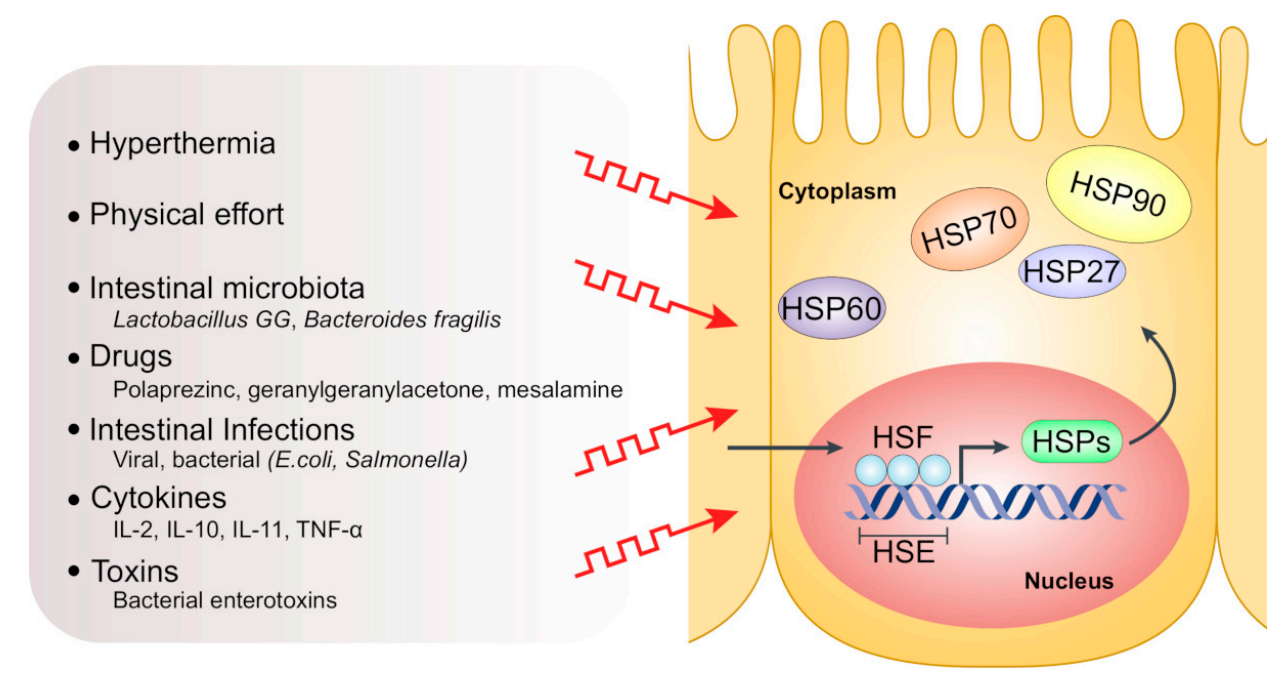

Figure 2. Factors inducing HSP expression in intestinal epithelial cells. In response to various stresses such as hyperthermia, intestinal infections, toxins and drugs, activated trimeric heat shock factor (HSF) translocates to the nucleus and binds to the heat shock element (HSE) in the promotor region of HSP genes, thus triggering HSP transcription.

It is apparent that the variability and multiplicity of HSPs' functions remain intriguing and need further in-depth investigations in terms of their cytoprotective, pathogenic or pro-oncogenic criteria [28,29]. Since HSPs are implicated in many house-keeping as well as pathological processes, we aim in the current review to demonstrate and summarize their roles in IBD, particularly those of HSP90, HSP70, HSP60 and small HSPs as major contributors to IBD, and further reveal the potential of their targeting to mitigate the progression or development of the disease.

\section{Heat Shock Proteins in IBD}

\subsection{HSP90}

There is accumulating evidence linking HSP90 expression to the pathogenesis of IBD. Expression of HSP90 was found to be elevated in the intestinal mucosa of patients with UC at the time of diagnosis and to be reduced after therapy [30]. It has been therefore postulated that HSP90, together with other chaperones like HSP70 and HSP60, contributes to the development and maintenance of IBD [30]. Previous contradicting results were reported by Stahl and his colleagues who demonstrated the absence of significant differences between HSP90 levels in healthy and IBD patients [31]. However, fluctuations in the aforementioned levels of HSPs before and after IBD treatments supported the suggestion of utilizing HSPs as useful biomarkers in this disease [30]. A pioneering work by de Zoeten et al. has 
revealed a key role for Foxp3+ T-regulatory cells (Tregs) in intestinal homeostasis. A reduced Foxp3+ Tregs population has been linked to autoimmune diseases and allograft rejection. These Tregs highly express various histone/protein deacetylases (HDACs) that influence many cellular activities including gene expression, protein function and chromatin remodeling [32]. Interestingly, pan-HDAC inhibition, that has been used for cancer treatment, could enrich Treg production and impact the acetylation status of other non-histone proteins. Of particular importance, targeted inhibition of the HDAC6 isoform (HDAC6i) has been shown to enhance the suppressive functions of Tregs, regulate the HSR and affect HSP90 acetylation [32].

Recent studies have shown that mitochondrial HSP90, tumor necrosis factor receptor-associated protein 1 (TRAP1), is highly expressed in UC patients and implicated in UC progression to UC-associated colorectal cancer [33]. On the other hand, expression of the ER chaperone GRP94 has been found lacking in intestinal macrophages (IMACs) of CD patients [34]. Deficient GRP94 in IMACs has been associated with deprivation of tolerance to gut microbiota and further development of chronic inflammation [34,35].

Interestingly, HSP90 inhibitors such as 17-allylaminogeldanamycin (17-AAG) have been found to suppress dextran sulfate sodium (DSS)-induced colitis [36]. In accordance with these results, Novobiocin, another inhibitor of HSP90, has been shown to mitigate DSS-induced colitis and CD45RB ${ }^{\text {high }}$ adoptive-transfer colitis in mice via reduction of secretory inflammatory cytokines such as TNF- $\alpha[37,38]$. In addition, the broad-spectrum antibiotic rifabutin, that has been used in IBD treatment strategies to limit UC symptoms, may also inhibit HSP90 [39]. However, a causal link remains to be proven [40] (see Table 2). Of note, this drug has been used primarily to protect against disseminated Mycobacterium avium complex infection in patients with advanced HIV infection, besides its effectiveness in treating multidrug-resistant Helicobacter pylori [40,41]. Furthermore, HSP90 inhibition has been actively investigated in many preclinical and clinical studies concerning gastrointestinal and colorectal cancers arising from IBD progression [6,42].

\section{2. $H S P 70$}

Generally, elevated expression of HSP70 has been reported in patients with intestinal inflammatory diseases compared with healthy individuals [21]. Studies with experimentally induced colitis in mice have shown that overexpression of HSPs was not a universal response for all HSPs. In colorectal mucosa, the expression levels of HSP70 and HSP40 were increased, whereas the levels of HSP25, HSP32 and HSP90 remained unaltered [43]. Similar findings, reflecting comparatively high HSP70 mucosal expression, have been reported in UC and CD human patients compared with healthy controls [44]. Notably, HSP70 expression can change in response to treatment type and duration. For instance, a six-month treatment of UC patients with 5-aminosalicylic acid (5-ASA) preparations and probiotics resulted in modulation of the HSP70 expression pattern from high to normal in healthy individuals [30]. These observations support the notion that IBD treatments including chemotherapeutics and antibiotics act to eliminate intestinal commensal bacteria which harbour epitopes necessary for appropriate HSP70 induction [45]. Moreover, the previous results suggest that measurement of HSP levels in the intestinal mucosa imply a strong potential for monitoring the response to treatment in IBD [30].

Previous reports have revealed the significance of HSP70 in the pathogenesis of IBD [21,46]. Ohkawara and co-workers have shown that mice expressing high levels of HSP70 and HSP40, as a result of macrophage migration inhibitory factor gene deletion, could resist pharmacologically induced colorectal inflammation. Subsequent inhibition of HSPs reversed the situation and resulted in the development of colorectal inflammation [43]. Another evidence for the pivotal role of HSP70 in IBD has been speculated from hyperthermia-induced expression of HSPs in mice. In these experiments, mice that had been primarily subjected to heat stress were tolerant to pharmacologically induced colitis compared to non-exposed animals [47].

It is of note that several inflammatory mediators and cytokines, including IL-10, IL-11, IL-1 $\beta$, TNF- $\alpha$, can induce HSPs to exert their cytoprotective effect [21]. IL-11 has been demonstrated to confer 
epithelial-specific cytoprotection via HSP25 but not HSP70 induction in models of intestinal epithelial injury $[48,49]$. Several in vivo studies point to HSP70 as an anti-inflammatory mediator in intestinal inflammation. In colorectal inflammation, mice highly expressing HSP70 exhibited lower macrophage activity in addition to dropped expression levels of pro-inflammatory cytokines including TNF- $\alpha$, IL-6, IL-1 $\beta$ compared to control animals. Moreover, the pathologic consequences were milder in animals with augmented HSP70 expression [50]. Furthermore, HSP70 has been reported to trigger IL-10 production with anti-inflammatory effects in model of bacterial infection with Listeria monocytogenes and in experimentally induced arthritis [51].

Indeed, besides inflammation-mediated HSP70 induction, many diverse factors including physiological microbiota contribute to HSP70 expression in the intestine. The terminal part of the small intestine, before the colonic junction, has displayed basal expression of HSP70 that has been attributed to potential contact with the colonic bacterial flora, able to impact its expression level in this region [52]. In addition, dietary components, food additives and physical activity such as exercise have a strong impact on HSP70 induction and intestinal epithelial protection $[21,53]$. All these factors can, therefore, contribute to the clinical course of IBD by HSP-mediated mechanisms. However, these conclusions need further investigation.

Several pieces of evidence implicate HSP70 isoforms in CD pathogenesis. For instance, a single nucleotide polymorphism in HSP70-2 (HSPA1B) has been reported to be involved in a severe clinical course of CD [54,55]. Notably, there are three common genotypes of HSP70-2, AA, AB and BB, resulting from A-G transitions at the 1267 position and producing a PstI site. Of those, the heterozygous genotype $\mathrm{AB}$ is the most frequently noticed in $\mathrm{CD}$ patients, while the $\mathrm{AA}$ and $\mathrm{BB}$ genotypes are associated with less severe forms of $\mathrm{CD}[56,57]$. In addition, de novo and rare mutations of HSPA1L have been found exclusively in patients with IBD. Further biochemical analyses of these mutations revealed incompetent chaperone activities [58]. Another interesting study has demonstrated that HSPA6 (also known as HSP70B') can be induced by cigarette smoke, resulting in protection of intestinal epithelial cells via stabilizing anti-apoptotic Bcl-XL [59].

The strong association between HSP70 upregulation in intestinal epithelium and the concurrent protective outcomes against detrimental factors could open new avenues to develop therapeutic approaches for intestinal diseases (see Table 2) [21]. For instance, geranylgeranylacetone, a substance that promotes HSP70 intestinal expression, has been shown to ameliorate or counteract the development of chemically induced colorectal inflammation [60,61]. Similarly, zinc compounds such as polaprezinc exhibited beneficial effects in preventing intestinal inflammation in mice concomitant with overexpression of HSP70 [62]. Polaprezinc has also been shown to protect against acetylsalicylic acid-induced intestinal injury [63]. Furthermore, compounds inhibiting HSP70 expression like quercetin abolished the anti-inflammatory effect of polaprezinc [64]. Interestingly, the anti-IBD drug mesalazine has been shown to augment HSP70 expression in cells of the colorectal mucosa after thermal induction, resulting in a better cytoprotection. Moreover, in an experimental model of large intestine inflammation, high doses of glutamine could upregulate both HSP70 and HSP25 and promote anti-inflammatory activity [65].

On the other hand, special considerations should be taken when using antibiotics for IBD treatment. Oral antibiotics that are used for the treatment of $C D$ have been reported to seriously impact the bacteria within the gut microbiota and consequently disturb HSPs intestinal expression $[66,67]$. A chronic metronidazole treatment in mice resulted in the reduction of colonic mucosal HSP25 and HSP72 expression and a higher susceptibility to the deleterious effects of bacterial toxins [48]. Similar results of HSP downregulation and even increased mortality were obtained when experimental animals were subjected to combination antibiotic treatments including metronidazole, ampicillin, neomycin and vancomycin $[48,68]$. Taken together, these observations denote that antibiotics can disrupt the physiological induction of HSPs and, hence, influence the intestinal vulnerability to infection and inflammation [69]. 
Table 2. Modulators of HSPs as a therapeutic strategy in preclinical and clinical studies of IBD.

\begin{tabular}{|c|c|c|c|}
\hline HSP Member & Compound & Action & Reference \\
\hline \multirow{3}{*}{ HSP90 } & 17-Allylaminogeldanamycin (17-AAG) & $\begin{array}{l}\text { - N-terminal ATPase-targeted HSP90 inhibitor } \\
\text { - Inhibits dextran sulfate sodium (DSS)-induced colitis } \\
\text { - Increases the production of anti-inflammatory cytokines including interleukin (IL)-10 in the colon } \\
\text { - Increases the suppressive function of Foxp3+ Tregs in vitro and in vivo. }\end{array}$ & {$[36,38]$} \\
\hline & Novobiocin & $\begin{array}{l}\text { - Inhibits the HSP90 C-terminal ATPase } \\
\text { - Attenuates dextran sulfate sodium-induced colitis and CD45RB }{ }^{\text {high }} \text { adoptive-transfer colitis }\end{array}$ & [37] \\
\hline & Rifabutin & $\begin{array}{l}\text { - Inhibits HSP90 } \\
\text { - Treats multidrug-resistant Helicobacter pylori }\end{array}$ & {$[40,41]$} \\
\hline \multirow{4}{*}{ HSP70 } & Geranylgeranylacetone & $\begin{array}{l}\text { - Enhances HSP70 expression } \\
\text { - Acyclic polyisoprenoid that protects the stomach from mucosal injury } \\
\text { - Protects against oxidative stressors including monocrolamine (NH2Cl) and } \\
\text { 2,4,6- trinitrobenzene sulfonic acid (TNBS) in mice. }\end{array}$ & {$[60,61]$} \\
\hline & $\begin{array}{c}\text { Polaprezinc } \\
\text { (N-(3-aminopropionyl)-L-histidinato } \\
\text { zinc) }\end{array}$ & $\begin{array}{l}\text { - Increases the expression of HSP70 } \\
\text { - Anti-inflammatory and anti-ulcer drug } \\
\text { - Protects against acetylsalicylic acid-induced intestinal injury as well as DSS-induced colitis in mice }\end{array}$ & {$[62,63]$} \\
\hline & Mesalamine & $\begin{array}{l}\text { - Supports thermal induction of HSP72 in intestinal epithelial cells } \\
\text { - Supports intestinal mucosal integrity and reduces inflammatory response }\end{array}$ & {$[70,71]$} \\
\hline & Glutamine & $\begin{array}{l}\text { - Increases the expression levels of both HSP70 and HSP27 in intestinal cells } \\
\text { - Protects intestinal cells against inflammation-induced stress } \\
\text { - Pharmacologic doses of glutamine lessen DSS-induced colitis in vivo }\end{array}$ & {$[65,72]$} \\
\hline \multirow[b]{2}{*}{ HSP60 } & $\begin{array}{l}\text { 5-Aminosalicylic acid } \\
\text { (5-ASA) }\end{array}$ & - Downregulation of HSP60 together with reduction of inflammation & [73] \\
\hline & Prozumab & $\begin{array}{l}\text { - Humanized anti-HSP monoclonal antibody able to bind HSP60 } \\
\text { - Counteracts murine inflammatory arthritis and colitis } \\
\text { - Stimulates interleukin } 10 \text { (IL-10) secretion from naive human peripheral blood mononuclear cells } \\
\text { (PBMCs) and decreases release of IFN- } \gamma \text { and IL-6 from anti-CD3-activated human PBMCs }\end{array}$ & [74] \\
\hline HSP27 & Butyrate & $\begin{array}{l}\text { - Enhances the expression of HSP27 } \\
\text { - Supports intestinal epithelial cells function and integrity } \\
\text { - Oral butyrate may augment the potency of oral mesalazine in active ulcerative colitis (UC) }\end{array}$ & [75-77] \\
\hline
\end{tabular}




\section{3. $H S P 60$}

Current reports strongly consider the mitochondrial chaperonin HSP60 as a major player in IBD pathogenesis and treatment [78]. To this end, Cappello and his colleagues enumerated several reasons supporting this hypothesis. Among these are: (a) The ability of HSP60 to stimulate pro-inflammatory cytokines [79-82]; (b) The variability of HSP60 levels in UC mucosa in response to the disease status [73,83]; (c) The implication of HSP60 in other inflammatory conditions such as atherosclerosis [23,84]; and finally (d) The "molecular mimicry" resulting from shared epitopes among human HSP60 and HSP60 from variant intestinal pathogenic microorganisms that ultimately leads to cross-reactivity and development of autoimmunity [25,85-87]. In addition, previous studies have revealed that HSP60 is upregulated in the lamina propria of the intestine in IBD patients compared to healthy individuals [83]. These findings suggest a potential role for HSP60 in inflammatory response activation [78]. In accordance with this conclusion, single or co-administration of 5-aminosalicylic acid (5-ASA) with probiotics to IBD patients resulted in mitigation of inflammation and simultaneous reduction of HSP60 expression levels [73,78].

An imbalance in gut microbiota has also been reported to impact HSP60 function in IBD [88]. Dietary probiotics led to lowered levels of HSP60 together with alteration in its post-translational modifications in mice models [89]. These reduced HSP60 concentrations have been attributed to HSP60 secretion into the extracellular milieu either in its soluble free form or via exosomes [90].

Early studies have shown that antibodies against HSP60 could be detected in patients with IBD [91,92]. Moreover, immunohistochemical studies have shown intense staining of HSP60 in mononuclear cells of the intestinal mucosa and submucosa in patients with CD as compared to the mucosal expression in patients with UC [91]. These observations have been evidenced by the co-expression of HSP60 and B7, a marker protein of antigen-presenting cells (APCs) which mediates T-cell activation in patients of IBD. The expression of HSP60 in B7-positive cells has been proposed to play a key role in T-cell activation and stimulation of the inflammatory process [91]. Furthermore, transfer of HSP60-reactive CD8+ T cells into mice resulted in a strong induction of intestinal inflammation that was MHC class I-dependent [93]. Importantly, the transferred HSP60-reactive CD8+ T cells were capable of causing the inflammatory condition regardless of the presence of intestinal bacterial flora. Thus, these findings indicate that HSP60-reactive CD8+ T cells were reactive to cellular HSP60 causing autoimmunity and a severe pathogenic form of colitis [78,93]. Additionally, monoclonal antibodies against HSP60 have been demonstrated to bind HSP60 and reduce inflammatory arthritis and colitis in mice [74]. In addition, studies on diseased children have revealed a strong contribution of HSP60 to the immune and inflammatory responses accompanying paediatric CD [94].

It should be noted that several studies link HSP60 to peritumoral inflammation along with clinical course of IBD. Unlike other chaperones, abundant intraepithelial expression of HSP60 has been reported during early stages of colon carcinogenesis, an observation that coincides with that of disturbed homeostasis of intestinal microbiota [95-99]. In cancer cells, HSP60 inhibits apoptosis via pro-caspase 3 binding [100]. Similarly, it associates with cyclophilin D (Cyp-D), preventing its binding to a multi-molecular complex comprising HSP90 and TRAP1, hence hindering tumour cell death [101]. Moreover, HSP60 supports cancer cell survival via a TNF- $\alpha$-mediated pathway [102]. HSP60 interacts directly with IKK $\alpha / \beta$, leading to activation of NF-kB target genes [102]. In addition, secretory forms of HSP60 have been reported to be frequently produced from tumour cells and show distinct posttranslational modifications $[90,103,104]$.

As previously presented, despite the involvement of HSP60 in the molecular mechanisms of diverse diseases including IBD, further investigations are required to fully unravel its molecular roles in IBD. Nevertheless, HSP60 has frequently been suggested as a possible therapeutic target in IBD [78]. In this respect, Meng and his colleagues have summarized the common natural as well as synthetic compounds that can modulate HSP60 levels and suggested that they can be clinically useful for the treatment of diseases including IBD in the near future [105]. 


\subsection{Small HSPS}

The fact that sHSPs are broadly associated with several intestinal pathologies makes them interesting targets to investigate in IBD. Alpha B-crystallin (CRYAB or HSPB5), a significant member of sHSPs, has been recently shown to regulate the intestinal inflammatory response in the intestinal mucosa. In vivo and in vitro studies have implicated CRYAB in the suppression of proinflammatory cytokines (e.g., TNF- $\alpha$, IL-6, IL-1 $\beta$ and IL-8) through inhibiting the formation of the IKK complex [106].

HSP27 is another inducible sHSP whose expression is relatively higher in colonic epithelium as compared to the small intestine. Similar to HSP70, the abundant HSP27 colonic expression has been attributed to stimulation by commensal microbes that exist in large amounts in the colon [48,52]. In addition, many bacteria and bacterial products can trigger HSP27 induction [69]. These include lipopolysaccharide (LPS), short-chain fatty acids (SCFAs), soluble factors from probiotic bacteria including Lactobacillus GG and Bifdobacterium breve and sporulating factor from Bacillus subtilis [76,107-110]. In line with this information, SCFAs such as butyrate, have been demonstrated to play beneficial roles in the treatment of IBD when supplemented with classical therapeutic agents like mesalazine and corticosteroids [75-77].

\section{Involvement of HSPs in the Progression of IBD to Cancer}

It is well known that the functions of HSPs are mainly directed towards cellular protection against various stresses. However, in many occasions, their functional outcomes shift to support tumorigenicity and cancer resistance to chemotherapy [111]. Overexpression of HSPs has been described in many types of cancer including prostate [29], ovarian [112], liver [113], lung [114] and colorectal cancer (CRC) $[115,116]$. In this respect, CRC stands as a serious, life-threatening complication arising from $\mathrm{CD}$ and according to statistics in 2014, it accounts for roughly $15 \%$ of IBD-related deaths [69,115]. For instance, HSP27 and HSP70, that are constitutively expressed in the intestinal epithelium, exhibit marked overexpression in CRC [117-119]. In addition, HSP27 has been found to support carcinogenesis through anti-apoptotic activities and multidrug resistance [120]. On the other hand, downregulation of specific HSPs has been suggested to contribute to cancer development. Mice lacking HSP70 expression have shown histological features of human IBD-associated colon cancer [121,122]. Moreover, the well-known causative agent of gastric cancer, $H$. pylori, decreases the proliferation of the gastric epithelium via epigenetic mechanisms and downregulation of HSP70 expression [123,124]. These findings indicate that fine-tuning HSPs' expression is a key process that impacts intestinal homeostasis and regulates HSPs' proposed functions in either cytoprotection or oncogenesis [69]. For this reason, there have been several endeavours to inhibit HSP-induced carcinogenesis and tumorigenesis through the use of HSP inhibitors or mutant HSPs. These efforts are aimed at sensitizing human colorectal cancer cells to chemotherapy or radiation therapy $[117,125,126]$. Furthermore, microbe-derived HSP vaccines against $H$. pylori have been developed and could induce protective immunity concurrent with a diminished inflammatory response [127].

\section{Conclusions and Perspectives}

Undoubtedly, HSPs are involved in intestinal homeostasis and pathophysiology. Many stress factors causing IBD can trigger the expression of HSPs. HSP90, HSP70, HSP60, HSP27 are key chaperones that protect against damage of the colorectal mucosa, and their increased expression affords cytoprotection and restricts IBD progression. In contrast, however, HSPs supports disease progression in the intestinal mucosa, according to stage of the disease and other poorly understood mechanisms. Therefore, understanding the regulation of HSP expression is essential to help slow down the clinical course of the disease. Taken together, pharmacological modulation of HSPs' expression represents a significant therapeutic approach, which may potentiate the current treatment regimens in patients with IBD. 
Author Contributions: A.H. and H.Y.N. conceived the review topic. A.H wrote the review draft and designed the figures. H.Y.N. edited and revised the review draft. Both authors approved the final version of the review.

Funding: This publication was supported by the Deutsche Forschungsgemeinschaft (DFG) and the University of Veterinary Medicine Hannover, Foundation within the funding programme Open Access Publishing.

Acknowledgments: AH was supported by a scholarship from the German Academic Exchange Service (DAAD), Bonn, Germany. The work cited in this paper from the authors' laboratory has been supported by grants from the German Research Foundation (DFG), Bonn, Germany and intramural funds of the University of Veterinary Medicine Hannover, Hannover, Germany.

Conflicts of Interest: The authors declare no conflict of interest.

\section{Abbreviations}

$\begin{array}{ll}\text { CD } & \text { Crohn's disease } \\ \text { DSS } & \text { Dextran sulfate sodium } \\ \text { HDAC } & \text { Histone/protein deacetylases } \\ \text { HIV } & \text { Human immunodeficiency virus } \\ \text { HSF1 } & \text { Heat Shock Factor 1 } \\ \text { HSPs } & \text { Heat shock proteins } \\ \text { HSR } & \text { Heat Shock Response } \\ \text { IBD } & \text { Inflammatory bowel disease } \\ \text { IKK } & \text { IkB kinase } \\ \text { IL } & \text { Interleukin } \\ \text { IMACs } & \text { Intestinal macrophages } \\ \text { sHSPs } & \text { Small heat shock proteins } \\ \text { TNF } & \text { Tumor Necrosis Factor } \\ \text { Tregs } & \text { T-regulatory cells } \\ \text { UC } & \text { Ulcerative colitis }\end{array}$

\section{References}

1. Kaser, A.; Zeissig, S.; Blumberg, R.S. Inflammatory bowel disease. Annu. Rev. Immunol. 2010, $28,573-621$. [CrossRef] [PubMed]

2. Maloy, K.J.; Powrie, F. Intestinal homeostasis and its breakdown in inflammatory bowel disease. Nature 2011, 474, 298-306. [CrossRef] [PubMed]

3. Holleran, G.; Lopetuso, L.; Petito, V.; Graziani, C.; Ianiro, G.; McNamara, D.; Gasbarrini, A.; Scaldaferri, F. The Innate and Adaptive Immune System as Targets for Biologic Therapies in Inflammatory Bowel Disease. Int. J. Mol. Sci. 2017, 18, 2020. [CrossRef] [PubMed]

4. Chotikatum, S.; Naim, H.Y.; El-Najjar, N. Inflammation induced ER stress affects absorptive intestinal epithelial cells function and integrity. Int. Immunopharmacol. 2018, 55, 336-344. [CrossRef]

5. Fiocchi, C. Inflammatory Bowel Disease: Complexity and Variability Need Integration. Front. Med. 2018, 5, 75. [CrossRef]

6. Chatterjee, S.; Burns, T.F. Targeting heat shock proteins in cancer: A promising therapeutic approach. Int. J. Mol. Sci. 2017, 18, 1978. [CrossRef]

7. Jee, H. Size dependent classification of heat shock proteins: A mini-review. J. Exerc. Rehabil. 2016, 12, $255-259$. [CrossRef]

8. Kampinga, H.H.; Hageman, J.; Vos, M.J.; Kubota, H.; Tanguay, R.M.; Bruford, E.A.; Cheetham, M.E.; Chen, B.; Hightower, L.E. Guidelines for the nomenclature of the human heat shock proteins. Cell Stress Chaperones 2009, 14, 105-111. [CrossRef]

9. Mattoo, R.U.H.; Goloubinoff, P. Molecular chaperones are nanomachines that catalytically unfold misfolded and alternatively folded proteins. Cell. Mol. Life Sci. 2014, 71, 3311-3325. [CrossRef]

10. Richter, K.; Haslbeck, M.; Buchner, J. The Heat Shock Response: Life on the Verge of Death. Mol. Cell 2010, 40, 253-266. [CrossRef]

11. Wiech, H.; Buchner, J.; Zimmermann, R.; Jakob, U. Hsp90 chaperones protein folding in vitro. Nature 1992, 358, 169-170. [CrossRef] [PubMed] 
12. Treweek, T.M.; Meehan, S.; Ecroyd, H.; Carver, J.A. Small heat-shock proteins: Important players in regulating cellular proteostasis. Cell. Mol. Life Sci. 2015, 72, 429-451. [CrossRef] [PubMed]

13. Hoter, A.; El-Sabban, M.E.; Naim, H.Y. The HSP90 Family: Structure, Regulation, Function, and Implications in Health and Disease. Int. J. Mol. Sci. 2018, 19, 2560. [CrossRef] [PubMed]

14. Srivastava, P. Roles of heat-shock proteins in innate and adaptive immunity. Nat. Rev. Immunol. 2002, 2, 185-194. [CrossRef] [PubMed]

15. Torigoe, T.; Tamura, Y.; Sato, N. Heat shock proteins and immunity: Application of hyperthermia for immunomodulation. Int. J. Hyperth. 2009, 25, 610-616. [CrossRef] [PubMed]

16. Zuo, D.; Subjeck, J.; Wang, X.-Y. Unfolding the Role of Large Heat Shock Proteins: New Insights and Therapeutic Implications. Front. Immunol. 2016, 7, 75. [CrossRef] [PubMed]

17. Hartl, F.U.; Bracher, A.; Hayer-Hartl, M. Molecular chaperones in protein folding and proteostasis. Nature 2011, 475, 324-332. [CrossRef]

18. Vihervaara, A.; Sistonen, L. HSF1 at a glance. Cell Sci. 2014, 127, 261-266. [CrossRef]

19. Lindquist, S. The heat-shock response. Annu. Rev. Biochem. 1986, 55, 1151-1191. [CrossRef]

20. Lindquist, S.; Craig, E.A. The heat-shock proteins. Annu. Rev. Genet. 1988, 22, 631-677. [CrossRef]

21. Samborski, P.; Grzymisławski, M. The Role of HSP70 Heat Shock Proteins in the Pathogenesis and Treatment of Inflammatory Bowel Diseases. Adv. Clin. Exp. Med. 2015, 24, 525-530. [CrossRef] [PubMed]

22. Spierings, J.; van Eden, W. Heat shock proteins and their immunomodulatory role in inflammatory arthritis. Rheumatology 2017, 56, 198-208. [CrossRef] [PubMed]

23. Wick, G.; Jakic, B.; Buszko, M.; Wick, M.C.; Grundtman, C. The role of heat shock proteins in atherosclerosis. Nat. Rev. Cardiol. 2014, 11, 516-529. [CrossRef] [PubMed]

24. Zilaee, M.; Shirali, S. Heat Shock Proteins and Diabetes. Can. J. Diabetes 2016, 40, 594-602. [CrossRef]

25. Gammazza, A.M.; Bucchieri, F.; Grimaldi, L.M.E.; Benigno, A.; de Macario, E.C.; Macario, A.J.L.; Zummo, G.; Cappello, F. The molecular anatomy of human Hsp60 and its similarity with that of bacterial orthologs and acetylcholine receptor reveal a potential pathogenetic role of anti-chaperonin immunity in myasthenia gravis. Cell. Mol. Neurobiol. 2012, 32, 943-947. [CrossRef]

26. Barbatis, C.; Tsopanomichalou, M. Heat shock proteins in inflammatory bowel disease. Ann. Gastroenterol. 2009, 22, 244-247.

27. Dudeja, V.; Vickers, S.M.; Saluja, A.K. The role of heat shock proteins in gastrointestinal diseases. Gut 2009, 58, 1000-1009. [CrossRef]

28. Calderwood, S.K. Heat shock proteins and cancer: Intracellular chaperones or extracellular signalling ligands? Philos. Trans. R. Soc. Lond. B Biol. Sci. 2018, 373. [CrossRef]

29. Hoter, A.; Rizk, S.; Naim, H.Y. The Multiple Roles and Therapeutic Potential of Molecular Chaperones in Prostate Cancer. Cancers 2019, 11, 1194. [CrossRef]

30. Tomasello, G.; Sciumé, C.; Rappa, F.; Rodolico, V.; Zerilli, M.; Martorana, A.; Cicero, G.; De Luca, R.; Damiani, P.; Accardo, F.M.; et al. Hsp10, Hsp70, and Hsp90 immunohistochemical levels change in ulcerative colitis after therapy. Eur. J. Histochem. 2011, 55, e38. [CrossRef]

31. Stahl, M.; Ludwig, D.; Fellermann, K.; Stange, E.F. Intestinal expression of human heat shock protein 90 in patients with Crohn's disease and ulcerative colitis. Dig. Dis. Sci. 1998, 43, 1079-1087. [CrossRef] [PubMed]

32. De Zoeten, E.F.; Wang, L.; Butler, K.; Beier, U.H.; Akimova, T.; Sai, H.; Bradner, J.E.; Mazitschek, R.; Kozikowski, A.P.; Matthias, P.; et al. Histone deacetylase 6 and heat shock protein 90 control the functions of Foxp3+ T-regulatory cells. Mol. Cell. Biol. 2011, 31, 2066-2078. [CrossRef] [PubMed]

33. Chen, R.; Pan, S.; Lai, K.; Lai, L.A.; Crispin, D.A.; Bronner, M.P.; Brentnall, T.A. Up-regulation of mitochondrial chaperone TRAP1 in ulcerative colitis associated colorectal cancer. World J. Gastroenterol. 2014, 20, 17037-17048. [CrossRef] [PubMed]

34. Wolfram, L.; Fischbeck, A.; Frey-Wagner, I.; Wojtal, K.A.; Lang, S.; Fried, M.; Vavricka, S.R.; Hausmann, M.; Rogler, G. Regulation of the Expression of Chaperone gp96 in Macrophages and Dendritic Cells. PLoS ONE 2013, 8. [CrossRef] [PubMed]

35. Schreiter, K.; Hausmann, M.; Spoettl, T.; Strauch, U.G.; Bataille, F.; Schoelmerich, J.; Herfarth, H.; Falk, W.; Rogler, G. Glycoprotein (gp) 96 expression: Induced during differentiation of intestinal macrophages but impaired in Crohn's disease. Gut 2005, 54, 935-943. [CrossRef] [PubMed]

36. Sai, H.; Hancock, W.W.; deZoeten, E.F. M1746 Inhibition of the HSP90 in FOXP3+ Tregs as a Novel Therapeutic Approach to Experimental Colitis. Gastroenterology 2010, 138, S-410-S-411. [CrossRef] 
37. Collins, C.B.; Strassheim, D.; Aherne, C.M.; Yeckes, A.R.; Jedlicka, P.; de Zoeten, E.F. Targeted inhibition of heat shock protein 90 suppresses tumor necrosis factor- $\alpha$ and ameliorates murine intestinal inflammation. Inflamm. Bowel Dis. 2014, 20, 685-694. [CrossRef]

38. Collins, C.B.; Aherne, C.M.; Yeckes, A.; Pound, K.; Eltzschig, H.K.; Jedlicka, P.; de Zoeten, E.F. Inhibition of N-terminal ATPase on HSP90 attenuates colitis through enhanced Treg function. Mucosal Immunol. 2013, 6, 960-971. [CrossRef]

39. Nitzan, O.; Elias, M.; Peretz, A.; Saliba, W. Role of antibiotics for treatment of inflammatory bowel disease. World J. Gastroenterol. 2016, 22, 1078-1087. [CrossRef]

40. Grenier, L.; Hu, P. Computational drug repurposing for inflammatory bowel disease using genetic information. Comput. Struct. Biotechnol. J. 2019, 17, 127-135. [CrossRef]

41. Lim, H.C.h.; Lee, Y.J.; An, B.; Lee, S.W.; Lee, Y.C.h.; Moon, B.S.o. Rifabutin-based high-dose proton-pump inhibitor and amoxicillin triple regimen as the rescue treatment for Helicobacter pylori. Helicobacter 2014, 19, 455-461. [CrossRef] [PubMed]

42. Moser, C.; Lang, S.A.; Stoeltzing, O. Heat-shock protein 90 (Hsp90) as a molecular target for therapy of gastrointestinal cancer. Anticancer Res. 2009, 29, 2031-2042. [PubMed]

43. Ohkawara, T.; Nishihira, J.; Ishiguro, Y.; Otsubo, E.; Nagai, K.; Takeda, H.; Kato, M.; Yoshiki, T.; Iwanaga, T.; Asaka, M. Resistance to experimental colitis depends on cytoprotective heat shock proteins in macrophage migration inhibitory factor null mice. Immunol. Lett. 2006, 107, 148-154. [CrossRef] [PubMed]

44. Ludwig, D.; Stahl, M.; Ibrahim, E.T.; Wenzel, B.E.; Drabicki, D.; Wecke, A.; Fellermann, K.; Stange, E.F. Enhanced intestinal expression of heat shock protein 70 in patients with inflammatory bowel diseases. Dig. Dis. Sci. 1999, 44, 1440-1447. [CrossRef]

45. Matsuo, K.; Zhang, X.; Ono, Y.; Nagatomi, R. Acute stress-induced colonic tissue HSP70 expression requires commensal bacterial components and intrinsic glucocorticoid. Brain. Behav. Immun. 2009, 23, 108-115. [CrossRef]

46. Otaka, M.; Odashima, M.; Watanabe, S. Role of heat shock proteins (molecular chaperones) in intestinal mucosal protection. Biochem. Biophys. Res. Commun. 2006, 348, 1-5. [CrossRef]

47. Otani, S.; Otaka, M.; Jin, M.; Okuyama, A.; Itoh, S.; Iwabuchi, A.; Sasahara, H.; Itoh, H.; Tashima, Y.; Masamune, O. Effect of preinduction of heat shock proteins on acetic acid-induced colitis in rats. Dig. Dis. Sci. 1997, 42, 833-846. [CrossRef]

48. Kojima, K.; Musch, M.W.; Ren, H.; Boone, D.L.; Hendrickson, B.A.; Ma, A.; Chang, E.B. Enteric flora and lymphocyte-derived cytokines determine expression of heat shock proteins in mouse colonic epithelial cells. Gastroenterology 2003, 124, 1395-1407. [CrossRef]

49. Ropeleski, M.J.; Tang, J.; Walsh-Reitz, M.M.; Musch, M.W.; Chang, E.B. Interleukin-11-induced heat shock protein 25 confers intestinal epithelial-specific cytoprotection from oxidant stress. Gastroenterology 2003, 124, 1358-1368. [CrossRef]

50. Tanaka, K.-I.; Namba, T.; Arai, Y.; Fujimoto, M.; Adachi, H.; Sobue, G.; Takeuchi, K.; Nakai, A.; Mizushima, T. Genetic evidence for a protective role for heat shock factor 1 and heat shock protein 70 against colitis. J. Biol. Chem. 2007, 282, 23240-23252. [CrossRef]

51. Borges, T.J.; Wieten, L.; van Herwijnen, M.J.C.; Broere, F.; van der Zee, R.; Bonorino, C.; van Eden, W. The anti-inflammatory mechanisms of Hsp70. Front. Immunol. 2012, 3, 95. [CrossRef] [PubMed]

52. Arvans, D.L.; Vavricka, S.R.; Ren, H.; Musch, M.W.; Kang, L.; Rocha, F.G.; Lucioni, A.; Turner, J.R.; Alverdy, J.; Chang, E.B. Luminal bacterial flora determines physiological expression of intestinal epithelial cytoprotective heat shock proteins 25 and 72. Am. J. Physiol. Gastrointest. Liver Physiol. 2005, 288, G696-G704. [CrossRef] [PubMed]

53. Arnal, M.E.; Lallés, J.P. Gut epithelial inducible heat-shock proteins and their modulation by diet and the microbiota. Nutr. Rev. 2016, 74, 181-197. [CrossRef] [PubMed]

54. Chen, J.; Ren, J.; Gu, G.; Wang, G.; Wu, X.; Yan, D.; Liu, S.; Li, J. Crohn's disease and polymorphism of heat shock protein gene HSP70-2 in the Chinese population. J. Gastroenterol. Hepatol. 2013, 28, 814-818. [CrossRef]

55. Zouiten-Mekki, L.; Karoui, S.; Kharrat, M.; Fekih, M.; Matri, S.; Boubaker, J.; Filali, A.; Chaabouni, H. Crohn's disease and polymorphism of heat shock protein gene HSP70-2 in the Tunisian population. Eur. J. Gastroenterol. Hepatol. 2007, 19, 225-228. [CrossRef]

56. Nam, S.Y.; Kim, N.; Kim, J.S.; Lim, S.H.; Jung, H.C.; Song, I.S. Heat shock protein gene 70-2 polymorphism is differentially associated with the clinical phenotypes of ulcerative colitis and Crohn's disease. J. Gastroenterol. Hepatol. 2007, 22, 1032-1038. [CrossRef] 
57. Tahara, T.; Shibata, T.; Okubo, M.; Ishizuka, T.; Kawamura, T.; Yamashita, H.; Nakamura, M.; Nakagawa, Y.; Nagasaka, M.; Arisawa, T.; et al. Heat-shock protein 70-2 BB genotype is associated with reduced risks of the steroid-dependent and refractory phenotypes of ulcerative colitis. Biomed. Rep. 2014, 2, 555-558. [CrossRef]

58. Takahashi, S.; Andreoletti, G.; Chen, R.; Munehira, Y.; Batra, A.; Afzal, N.A.; Beattie, R.M.; Bernstein, J.A.; Ennis, S.; Snyder, M. De novo and rare mutations in the HSPA1L heat shock gene associated with inflammatory bowel disease. Genome Med. 2017, 9, 8. [CrossRef]

59. Regeling, A.; Imhann, F.; Volders, H.H.; Blokzijl, T.; Bloks, V.W.; Weersma, R.K.; Dijkstra, G.; Faber, K.N. HSPA6 is an ulcerative colitis susceptibility factor that is induced by cigarette smoke and protects intestinal epithelial cells by stabilizing anti-apoptotic Bcl-XL. Biochim. Biophys. Acta Mol. Basis Dis. 2016, 1862, 788-796. [CrossRef]

60. Ohkawara, T.; Nishihira, J.; Takeda, H.; Katsurada, T.; Kato, K.; Yoshiki, T.; Sugiyama, T.; Asaka, M. Protective effect of geranylgeranylacetone on trinitrobenzene sulfonic acid-induced colitis in mice. Int. J. Mol. Med. 2006, 17, 229-234. [CrossRef]

61. Ohkawara, T.; Takeda, H.; Nishiwaki, M.; Nishihira, J.; Asaka, M. Protective effects of heat shock protein 70 induced by geranylgeranylacetone on oxidative injury in rat intestinal epithelial cells. Scand. J. Gastroenterol. 2006, 41, 312-317. [CrossRef] [PubMed]

62. Ohkawara, T.; Takeda, H.; Kato, K.; Miyashita, K.; Kato, M.; Iwanaga, T.; Asaka, M. Polaprezinc ( $N$-(3-aminopropionyl)-L-histidinato zinc) ameliorates dextran sulfate sodium-induced colitis in mice. Scand. J. Gastroenterol. 2005, 40, 1321-1327. [CrossRef] [PubMed]

63. Qin, Y.; Naito, Y.; Handa, O.; Hayashi, N.; Kuki, A.; Mizushima, K.; Omatsu, T.; Tanimura, Y.; Morita, M.; Adachi, S.; et al. Heat shock protein 70-dependent protective effect of polaprezinc on acetylsalicylic acid-induced apoptosis of rat intestinal epithelial cells. J. Clin. Biochem. Nutr. 2011, 49, 174-181. [CrossRef] [PubMed]

64. Ohkawara, T.; Nishihira, J.; Nagashima, R.; Takeda, H.; Asaka, M. Polaprezinc protects human colon cells from oxidative injury induced by hydrogen peroxide: Relevant to cytoprotective heat shock proteins. World J. Gastroenterol. 2006, 12, 6178-6181. [CrossRef] [PubMed]

65. Xue, H.; Sufit, A.J.D.; Wischmeyer, P.E. Glutamine therapy improves outcome of in vitro and in vivo experimental colitis models. JPEN J. Parenter. Enteral Nutr. 2011, 35, 188-197. [CrossRef]

66. Francino, M.P. Antibiotics and the Human Gut Microbiome: Dysbioses and Accumulation of Resistances. Front. Microbiol. 2015, 6, 1543. [CrossRef]

67. Khan, K.J.; Ullman, T.A.; Ford, A.C.; Abreu, M.T.; Abadir, A.; Abadir, A.; Marshall, J.K.; Talley, N.J.; Moayyedi, P. Antibiotic therapy in inflammatory bowel disease: A systematic review and meta-analysis. Am. J. Gastroenterol. 2011, 106, 661-673. [CrossRef]

68. Rakoff-Nahoum, S.; Paglino, J.; Eslami-Varzaneh, F.; Edberg, S.; Medzhitov, R. Recognition of commensal microflora by toll-like receptors is required for intestinal homeostasis. Cell 2004, 118, 229-241. [CrossRef]

69. Finlayson-Trick, E.; Connors, J.; Stadnyk, A.; Van Limbergen, J. Regulation of Antimicrobial Pathways by Endogenous Heat Shock Proteins in Gastrointestinal Disorders. Gastrointest. Disord. 2018, 10, 5. [CrossRef]

70. Burress, G.C.; Musch, M.W.; Jurivich, D.A.; Welk, J.; Chang, E.B. Effects of mesalamine on the hsp72 stress response in rat IEC-18 intestinal epithelial cells. Gastroenterology 1997, 113, 1474-1479. [CrossRef]

71. Baumgart, D.C.; Vierziger, K.; Sturm, A.; Wiedenmann, B.; Dignass, A.U. Mesalamine promotes intestinal epithelial wound healing in vitro through a TGF- $\beta$-independent mechanism. Scand. J. Gastroenterol. 2005, 40, 958-964. [CrossRef] [PubMed]

72. Musch, M.W.; Hayden, D.; Sugi, K.; Straus, D.; Chang, E.B. Cell-specific induction of hsp72-mediated protection by glutamine against oxidant injury in IEC18 cells. Proc. Assoc. Am. Physicians 1998, 110, 136-139. [PubMed]

73. Tomasello, G.; Rodolico, V.; Zerilli, M.; Martorana, A.; Bucchieri, F.; Pitruzzella, A.; Gammazza, A.M.; David, S.; Rappa, F.; Zummo, G.; et al. Changes in immunohistochemical levels and subcellular localization after therapy and correlation and colocalization with CD68 suggest a pathogenetic role of Hsp60 in ulcerative colitis. Appl. Immunohistochem. Mol. Morphol. 2011, 19, 552-561. [CrossRef] [PubMed]

74. Ulmansky, R.; Landstein, D.; Moallem, E.; Loeb, V.; Levin, A.; Meyuhas, R.; Katzavian, G.; Yair, S.; Naparstek, Y. A Humanized Monoclonal Antibody against Heat Shock Protein 60 Suppresses Murine Arthritis and Colitis and Skews the Cytokine Balance toward an Anti-Inflammatory Response. J. Immunol. 2015, 194, 5103-5109. [CrossRef] [PubMed] 
75. Vernia, P.; Monteleone, G.; Grandinetti, G.; Villotti, G.; Di Giulio, E.; Frieri, G.; Marcheggiano, A.; Pallone, F.; Caprilli, R.; Torsoli, A. Combined oral sodium butyrate and mesalazine treatment compared to oral mesalazine alone in ulcerative colitis: Randomized, double-blind, placebo-controlled pilot study. Dig. Dis. Sci. 2000, 45, 976-981. [CrossRef] [PubMed]

76. Ren, H.; Musch, M.W.; Kojima, K.; Boone, D.; Ma, A.; Chang, E.B. Short-chain fatty acids induce intestinal epithelial heat shock protein 25 expression in rats and IEC 18 cells. Gastroenterology 2001, 121, 631-639. [CrossRef] [PubMed]

77. Tralongo, P.; Tomasello, G.; Sinagra, E.; Damiani, P.; Leone, A.; Palumbo, V.; Giammanco, M.; Di Majo, D.; Damiani, F.; Abruzzo, A.; et al. The role of butyric acid as a protective agent against inflammatory bowel diseases. EuroMediterranean Biomed. J. 2018. [CrossRef]

78. Cappello, F.; Mazzola, M.; Jurjus, A.; Zeenny, M.-N.; Jurjus, R.; Carini, F.; Leone, A.; Bonaventura, G.; Tomasello, G.; Bucchieri, F.; et al. Hsp60 as a Novel Target in IBD Management: A Prospect. Front. Pharmacol. 2019, 10, 26. [CrossRef]

79. Sangiorgi, C.; Vallese, D.; Gnemmi, I.; Bucchieri, F.; Balbi, B.; Brun, P.; Leone, A.; Giordano, A.; Conway de Macario, E.; Macario, A.J.L.; et al. HSP60 activity on human bronchial epithelial cells. Int. J. Immunopathol. Pharmacol. 2017, 30, 333-340. [CrossRef]

80. Cheong, H.C.; Lee, C.Y.Q.; Cheok, Y.Y.; Shankar, E.M.; Sabet, N.S.; Tan, G.M.Y.; Movahed, E.; Yeow, T.C.; Sulaiman, S.; Wong, W.F.; et al. CPAF, HSP60 and MOMP antigens elicit pro-inflammatory cytokines production in the peripheral blood mononuclear cells from genital Chlamydia trachomatis-infected patients. Immunobiology 2019, 224, 34-41. [CrossRef]

81. Sun, Y.; Zheng, J.; Xu, Y.; Zhang, X. Paraquat-induced inflammatory response of microglia through HSP60/TLR4 signaling. Hum. Exp. Toxicol. 2018, 37, 1161-1168. [CrossRef] [PubMed]

82. Swaroop, S.; Mahadevan, A.; Shankar, S.K.; Adlakha, Y.K.; Basu, A. HSP60 critically regulates endogenous IL-1 $\beta$ production in activated microglia by stimulating NLRP3 inflammasome pathway. J. Neuroinflammation 2018, 15, 177. [CrossRef]

83. Rodolico, V.; Tomasello, G.; Zerilli, M.; Martorana, A.; Pitruzzella, A.; Gammazza, A.M.; David, S.; Zummo, G.; Damiani, P.; Accomando, S.; et al. Hsp60 and Hsp10 increase in colon mucosa of Crohn's disease and ulcerative colitis. Cell Stress Chaperones 2010, 15, 877-884. [CrossRef]

84. Wick, C. Tolerization against atherosclerosis using heat shock protein 60. Cell Stress Chaperones 2016, 21, 201-211. [CrossRef] [PubMed]

85. Bachmaier, K.; Penninger, J.M. Chlamydia and antigenic mimicry. Curr. Top. Microbiol. Immunol. 2005, 296, 153-163. [CrossRef] [PubMed]

86. Loshaj-Shala, A.; Regazzoni, L.; Daci, A.; Orioli, M.; Brezovska, K.; Panovska, A.P.; Beretta, G.; Suturkova, L. Guillain Barré syndrome (GBS): New insights in the molecular mimicry between C. jejuni and human peripheral nerve (HPN) proteins. J. Neuroimmunol. 2015, 289, 168-176. [CrossRef]

87. Buhlin, K.; Holmer, J.; Gustafsson, A.; Hörkkö, S.; Pockley, A.G.; Johansson, A.; Paju, S.; Klinge, B.; Pussinen, P.J. Association of periodontitis with persistent, pro-atherogenic antibody responses. J. Clin. Periodontol. 2015, 42, 1006-1114. [CrossRef]

88. Bellavia, M.; Tomasello, G.; Romeo, M.; Damiani, P.; Lo Monte, A.I.; Lozio, L.; Campanella, C.; Marino Gammazza, A.; Rappa, F.; Zummo, G.; et al. Gut microbiota imbalance and chaperoning system malfunction are central to ulcerative colitis pathogenesis and can be counteracted with specifically designed probiotics: A working hypothesis. Med. Microbiol. Immunol. 2013, 202, 393-406. [CrossRef]

89. Barone, R.; Rappa, F.; Macaluso, F.; Caruso Bavisotto, C.; Sangiorgi, C.; Di Paola, G.; Tomasello, G.; Di Felice, V.; Marcianò, V.; Farina, F.; et al. Alcoholic Liver Disease: A Mouse Model Reveals Protection by Lactobacillus fermentum. Clin. Transl. Gastroenterol. 2016, 7, e138. [CrossRef]

90. Campanella, C.; D’Anneo, A.; Marino Gammazza, A.; Caruso Bavisotto, C.; Barone, R.; Emanuele, S.; Lo Cascio, F.; Mocciaro, E.; Fais, S.; Conway De Macario, E.; et al. The histone deacetylase inhibitor SAHA induces HSP60 nitration and its extracellular release by exosomal vesicles in human lung-derived carcinoma cells. Oncotarget 2016, 7, 28849-28867. [CrossRef]

91. Peetermans, W.E.; D’Haens, G.R.; Ceuppens, J.L.; Rutgeerts, P.; Geboes, K. Mucosal expression by B7-positive cells of the 60-kilodalton heat-shock protein in inflammatory bowel disease. Gastroenterology 1995, 108, 75-82. [CrossRef] 
92. Elsaghier, A.; Prantera, C.; Bothamley, G.; Wilkins, E.; Jindal, S.; Ivanyi, J. Disease association of antibodies to human and mycobacterial hsp70 and hsp60 stress proteins. Clin. Exp. Immunol. 1992, 89, 305-309. [CrossRef] [PubMed]

93. Steinhoff, U.; Brinkmann, V.; Klemm, U.; Aichele, P.; Seiler, P.; Brandt, U.; Bland, P.W.; Prinz, I.; Zügel, U.; Kaufmann, S.H. Autoimmune intestinal pathology induced by hsp60-specific CD8 T cells. Immunity 1999, 11, 349-358. [CrossRef]

94. Puga Yung, G.L.; Fidler, M.; Albani, E.; Spermon, N.; Teklenburg, G.; Newbury, R.; Schechter, N.; van den Broek, T.; Prakken, B.; Billetta, R.; et al. Heat shock protein-derived T-cell epitopes contribute to autoimmune inflammation in pediatric Crohn's disease. PLoS ONE 2009, 4, e7714. [CrossRef] [PubMed]

95. Cappello, F.; Bellafiore, M.; Palma, A.; David, S.; Marcianò, V.; Bartolotta, T.; Sciumè, C.; Modica, G.; Farina, F.; Zummo, G.; et al. 60KDa chaperonin (HSP60) is over-expressed during colorectal carcinogenesis. Eur. J. Histochem. 2003, 47, 105-110. [CrossRef]

96. Kang, M.; Martin, A. Microbiome and colorectal cancer: Unraveling host-microbiota interactions in colitis-associated colorectal cancer development. Semin. Immunol. 2017, 32, 3-13. [CrossRef]

97. Cappello, F.; David, S.; Rappa, F.; Bucchieri, F.; Marasà, L.; Bartolotta, T.E.; Farina, F.; Zummo, G. The expression of HSP60 and HSP10 in large bowel carcinomas with lymph node metastase. BMC Cancer 2005, 5, 139. [CrossRef]

98. Campanella, C.; Rappa, F.; Sciumè, C.; Marino Gammazza, A.; Barone, R.; Bucchieri, F.; David, S.; Curcurù, G.; Caruso Bavisotto, C.; Pitruzzella, A.; et al. Heat shock protein 60 levels in tissue and circulating exosomes in human large bowel cancer before and after ablative surgery. Cancer 2015, 121, 3230-3239. [CrossRef]

99. Rappa, F.; Pitruzzella, A.; Marino Gammazza, A.; Barone, R.; Mocciaro, E.; Tomasello, G.; Carini, F.; Farina, F.; Zummo, G.; Conway de Macario, E.; et al. Quantitative patterns of Hsps in tubular adenoma compared with normal and tumor tissues reveal the value of Hsp10 and Hsp60 in early diagnosis of large bowel cancer. Cell Stress Chaperones 2016, 21, 927-933. [CrossRef]

100. Campanella, C.; Bucchieri, F.; Ardizzone, N.M.; Marino Gammazza, A.; Montalbano, A.; Ribbene, A.; Di Felice, V.; Bellafiore, M.; David, S.; Rappa, F.; et al. Upon oxidative stress, the antiapoptotic Hsp60/procaspase-3 complex persists in mucoepidermoid carcinoma cells. Eur. J. Histochem. 2008, 52, 221-228. [CrossRef]

101. Ghosh, J.C.; Siegelin, M.D.; Dohi, T.; Altieri, D.C. Heat shock protein 60 regulation of the mitochondrial permeability transition pore in tumor cells. Cancer Res. 2010, 70, 8988-8993. [CrossRef] [PubMed]

102. Chun, J.N.; Choi, B.; Lee, K.W.; Lee, D.J.; Kang, D.H.; Lee, J.Y.; Song, I.S.; Kim, H.I.; Lee, S.-H.; Kim, H.S.; et al. Cytosolic Hsp60 is involved in the NF-kappaB-dependent survival of cancer cells via IKK regulation. PLoS ONE 2010, 5, e9422. [CrossRef] [PubMed]

103. Gorska, M.; Marino Gammazza, A.; Zmijewski, M.A.; Campanella, C.; Cappello, F.; Wasiewicz, T.; Kuban-Jankowska, A.; Daca, A.; Sielicka, A.; Popowska, U.; et al. Geldanamycin-induced osteosarcoma cell death is associated with hyperacetylation and loss of mitochondrial pool of heat shock protein 60 (hsp60). PLoS ONE 2013, 8, e71135. [CrossRef] [PubMed]

104. Marino Gammazza, A.; Campanella, C.; Barone, R.; Caruso Bavisotto, C.; Gorska, M.; Wozniak, M.; Carini, F.; Cappello, F.; D'Anneo, A.; Lauricella, M.; et al. Doxorubicin anti-tumor mechanisms include Hsp60 post-translational modifications leading to the Hsp60/p53 complex dissociation and instauration of replicative senescence. Cancer Lett. 2017, 385, 75-86. [CrossRef] [PubMed]

105. Meng, Q.; Li, B.X.; Xiao, X. Toward Developing Chemical Modulators of Hsp60 as Potential Therapeutics. Front. Mol. Biosci. 2018, 5, 35. [CrossRef] [PubMed]

106. Xu, W.; Guo, Y.; Huang, Z.; Zhao, H.; Zhou, M.; Huang, Y.; Wen, D.; Song, J.; Zhu, Z.; Sun, M.; et al. Small heat shock protein CRYAB inhibits intestinal mucosal inflammatory responses and protects barrier integrity through suppressing IKK $\beta$ activity. Mucosal Immunol. 2019. [CrossRef]

107. Kojima, K.; Musch, M.W.; Ropeleski, M.J.; Boone, D.L.; Ma, A.; Chang, E.B. Escherichia coli LPS induces heat shock protein 25 in intestinal epithelial cells through MAP kinase activation. Am. J. Physiol. Gastrointest. Liver Physiol. 2004, 286, G645-G652. [CrossRef]

108. Koninkx, J.F.J.G.; Tooten, P.C.J.; Malago, J.J. Probiotic bacteria induced improvement of the mucosal integrity of enterocyte-like Caco-2 cells after exposure to Salmonella enteritidis 857. J. Funct. Foods 2010, 2, 225-234. [CrossRef]

109. Morrison, D.J.; Preston, T. Formation of short chain fatty acids by the gut microbiota and their impact on human metabolism. Gut Microbes 2016, 7, 189-200. [CrossRef] 
110. Okamoto, K.; Fujiya, M.; Nata, T.; Ueno, N.; Inaba, Y.; Ishikawa, C.; Ito, T.; Moriichi, K.; Tanabe, H.; Mizukami, Y.; et al. Competence and sporulation factor derived from Bacillus subtilis improves epithelial cell injury in intestinal inflammation via immunomodulation and cytoprotection. Int. J. Colorectal Dis. 2012, 27, 1039-1046. [CrossRef]

111. Wu, J.; Liu, T.; Rios, Z.; Mei, Q.; Lin, X.; Cao, S. Heat Shock Proteins and Cancer. Trends Pharmacol. Sci. 2017, 38, 226-256. [CrossRef] [PubMed]

112. Hoter, A.; Naim, H.Y. Heat Shock Proteins and Ovarian Cancer: Important Roles and Therapeutic Opportunities. Cancers 2019, 11, 1389. [CrossRef] [PubMed]

113. Wang, C.; Zhang, Y.; Guo, K.; Wang, N.; Jin, H.; Liu, Y.; Qin, W. Heat shock proteins in hepatocellular carcinoma: Molecular mechanism and therapeutic potential. Int. J. Cancer 2016, 138, 1824-1834. [CrossRef] [PubMed]

114. Rong, B.; Yang, S. Molecular mechanism and targeted therapy of Hsp90 involved in lung cancer: New discoveries and developments (Review). Int. J. Oncol. 2018, 52, 321-336. [CrossRef] [PubMed]

115. Lasry, A.; Zinger, A.; Ben-Neriah, Y. Inflammatory networks underlying colorectal cancer. Nat. Immunol. 2016, 17, 230-240. [CrossRef]

116. Lee, S.L.; Dempsey-Hibbert, N.C.; Vimalachandran, D.; Wardle, T.D.; Sutton, P.; Williams, J.H.H. Heat Shock Protein-Based Therapies. In Targeting Heat Shock Proteins in Colorectal Cancer BT; Asea, A.A.A., Almasoud, N.N., Krishnan, S., Kaur, P., Eds.; Springer International Publishing: Cham, Switzerland, 2015; ISBN 978-3-319-17211-8.

117. Jagadish, N.; Parashar, D.; Gupta, N.; Agarwal, S.; Suri, V.; Kumar, R.; Suri, V.; Sadasukhi, T.C.; Gupta, A.; Ansari, A.S.; et al. Heat shock protein 70-2 (HSP70-2) is a novel therapeutic target for colorectal cancer and is associated with tumor growth. BMC Cancer 2016, 16, 561. [CrossRef]

118. Soleimani, A.; Zahiri, E.; Ehtiati, S.; Norouzi, M.; Rahmani, F.; Fiuji, H.; Avan, A.; Ferns, G.A.; Khazaei, M.; Hashemy, S.I.; et al. Therapeutic potency of heat-shock protein-70 in the pathogenesis of colorectal cancer: Current status and perspectives. Biochem. Cell Biol. 2019, 97, 85-90. [CrossRef]

119. Yu, Z.; Zhi, J.; Peng, X.; Zhong, X.; Xu, A. Clinical significance of HSP27 expression in colorectal cancer. Mol. Med. Rep. 2010, 3, 953-958. [CrossRef]

120. Heinrich, J.C.; Donakonda, S.; Haupt, V.J.; Lennig, P. New HSP27 inhibitors efficiently down-regulate resistance development in cancer cells. Oncotarget 2016, 7, 68156-68169. [CrossRef]

121. Tao, Y.; Hart, J.; Lichtenstein, L.; Joseph, L.J.; Ciancio, M.J.; Hu, S.; Chang, E.B.; Bissonnette, M. Inducible heat shock protein 70 prevents multifocal flat dysplastic lesions and invasive tumors in an inflammatory model of colon cancer. Carcinogenesis 2009, 30, 175-182. [CrossRef]

122. Hu, S.; Zhu, X.; Triggs, J.R.; Tao, Y.; Wang, Y.; Lichtenstein, L.; Bissonnette, M.; Musch, M.W.; Chang, E.B. Inflammation-induced, 3'UTR-dependent translational inhibition of Hsp70 mRNA impairs intestinal homeostasis. Am. J. Physiol. Gastrointest. Liver Physiol. 2009, 296, G1003-G1011. [CrossRef] [PubMed]

123. Tao, L.; Zou, H.; Huang, Z. Effects of Helicobacter pylori and Heat Shock Protein 70 on the Proliferation of Human Gastric Epithelial Cells. Gastroenterol. Res. Pract. 2014, 2014, 794342. [CrossRef] [PubMed]

124. Asea, A.A.A. Heat Shock Proteins. In HSP70 in Human Diseases and Disorders; Asea, A.A.A., Kaur, P., Eds.; Springer International Publishing: Cham, Germany, 2018; Volume 14, ISBN 978-3-319-89550-5.

125. Shevtsov, M.; Multhoff, G. Heat shock protein-Peptide and HSP-based immunotherapies for the treatment of cancer. Front. Immunol. 2016, 7, 1-7. [CrossRef] [PubMed]

126. Jhaveri, K.; Ochiana, S.O.; Dunphy, M.P.S.; Gerecitano, J.F.; Corben, A.D.; Peter, R.I.; Janjigian, Y.Y.; Gomes-DaGama, E.M.; Koren, J.; Modi, S.; et al. Heat shock protein 90 inhibitors in the treatment of cancer: Current status and future directions. Expert Opin. Investig. Drugs 2014, 23, 611-628. [CrossRef] [PubMed]

127. Chionh, Y.T.; Arulmuruganar, A.; Venditti, E.; Ng, G.Z.; Han, J.-X.; Entwisle, C.; Ang, C.-S.; Colaco, C.A.; McNulty, S.; Sutton, P. Heat shock protein complex vaccination induces protection against Helicobacter pylori without exogenous adjuvant. Vaccine 2014, 32, 2350-2358. [CrossRef]

(C) 2019 by the authors. Licensee MDPI, Basel, Switzerland. This article is an open access article distributed under the terms and conditions of the Creative Commons Attribution (CC BY) license (http://creativecommons.org/licenses/by/4.0/). 